https://doi.org/10.36909/jer.v9iICRIE.11647

\title{
Flexural Behavior of Damaged Lightweight Reinforced Concrete Beams Strengthened by CFRP
}

\author{
Ali I. Salahaldin*, Muyasser M. Jomaa'h** and Dlovan M. Naser** \\ *Department of Civil Engineering, College of Engineering, University of Kirkuk, IRAQ. \\ **Department of Civil Engineering, College of Engineering, Tikrit University, IRAQ. \\ *Email: ali.ihsan@uokirkuk.edu.iq; Corresponding Author.
}

\begin{abstract}
One of the most common methods of strengthening, rehabilitation, or repairing of structural lightweight concrete (LWC) elements is the external carbon fiber reinforced polymer (CFRP) strips. This paper presents an experimental study on the flexural behavior of reinforced concrete beams which comprise lightweight aggregate concrete, in different proportions, strengthened by CFRP sheets. The experimental program included six specimens with a $1500 \mathrm{~mm}$ effective span. Two of the specimens were normal concrete beams. Another two samples were lightweight beams with a 50\% aggregate replacement with pumice. The last two specimens were lightweight concrete beams with a $75 \%$ aggregate replacement with pumice. These beams were casted and tested twice under a two-point load application, once before strengthening and the other after that. The experimental results show that full strengthening of the beams along with their entire length, increase in load-carrying capacity by $75 \%, 113 \%$, and $107 \%$ for normal concrete beam, (50\% aggregate replacement) LWC beam, and (75\% aggregate replacement) LWC beam respectively. While the middle-third strengthening of the beams shows an increase in load-carrying capacity by $64 \%, 72 \%$, and $57 \%$ for normal concrete beam, (50\% aggregate replacement) LWC aggregate beam, and (75\% aggregate replacement) LWC beam respectively. The strength of the two types of LWC beams was almost the same and it is about $85 \%$ of the concrete beam with normal weight.
\end{abstract}


Key words: Pumice; Strengthening; Lightweight Concrete; CFRP; Flexural Behavior.

\section{INTRODUCATION}

The world is currently moving towards developing a new form of concrete using greentechnology to reduce pollution and construction costs (Hussein et al., 2016). Lightweight concrete LWC considered to be eco-friendly. It has a lower density than normal-weight concrete NWC and therefore reduces the construction cost by reducing the applied dead loads (Omer \&Mohamed, 2002). Lightweight concrete structures have many advantages such as giving the structural elements more efficient strength-to-weight ratio, possessing superior thermal insulation properties and higher fire resistance in compare to normal-weight concrete (Xu et al., 2012). It has various names depending on the way of producing (cellular LWC, lime LWC, and foamed LWC). The density of lightweight concrete ranges from1400 to $2000 \mathrm{Kg} / \mathrm{m}^{3}$ as compared to the density of the normal-weight concrete which has a range of 2200 to $2400 \mathrm{Kg} / \mathrm{m}^{3}$ (Shabeeb et al. 2012).

One of the lightweight aggregate types that are used in construction is pumice. Pumice is a natural substance of volcanic origin that results from the release of gases during a lava hardening. The cellular structure of the pumice is formed by creating bubbles or air voids while the gases in the molten lava flowing from the volcanoes are trapped during the cooling process (Khandaker\& Hossain, 2004). Many investigators have shown that with certain treatments, pumice (lightweight concrete) could be classified as a structural concrete. Al-Rawi (1995), Ghaidan (2018), and Al-Mamoori (2018) have discussed the mixture properties and characteristics of the LWC which varies based on the origin of the aggregates.

There are various techniques available for the rehabilitation and strengthening of deteriorated structures. One of the emerging techniques is the utilize of the fiber-reinforced polymer FRP. Many researchers found that FRP is a reliable, effective, and cost-efficient way 
for strengthening reinforced concrete structures (Ziraba et al., 1994). FRP laminates have many advantages such high stiffness to weight ratio, high tensile resistance, high resistance to fatigue ratio, corrosion resistance, and easy to handle in construction. Furthermore, the FRP strengthening techniques are becoming competitive with conventional strengthening techniques using steel plates (Nanni, 1999, as cited in Benjeddou et al., 2007).

One of the most challenging applications of FRP materials is the flexural strengthening of reinforced concrete beams. Comprehensive experimental and theoretical researches have been conducted on the flexural strength of the concrete beams strengthened with different FRP bonded types. Reinforced concrete beams strengthened with FRP sheets have four modes of failure: (1) disassembly failure; (2) rupture of FRP; (3) failure in compression and (4) failure in shear (Bonacci \& Maalej, 2001). Among the types of FRP, the research community has given attention to the applications of the CFRP in strengthening and repairing concrete beams. Faza and Ganga (1994) as cited in Benjeddou et al. (2007) showed that when the CFRP laminates are wrapped around beams, the strength increased by $200 \%$.

Carbon Fiber Reinforced Polymers (CFRP) sheets are relatively expansive compared with other FRP composite types, with high electric conductivity, and fail in a brittle manner due to its linear behavior until the failure. CFRP may be a good alternative to traditional materials for rehabilitation and repairing of existent reinforced concrete structures and used in new buildings as a substitute to steel reinforcement (Soudki et al.2007, Zaman et al. 2013, Kalavagunta et al. 2014, Danraka et al. 2017, \& Dushimimana et al.2018). A good guide for the analysis and design of these types of structural elements can be found in the American Concrete Manual ACI 440.2R (2008).

Limited researches were performed on the use of the FRP laminates in lightweight concrete structures. Yazdani and Goucher (2015) studied the influence of the FRP warps on lightweight 
concrete durability improvement, and they concluded that the FRP sheets can reduce the steel corrosion effectively with continuous improvement in the durability.

This research presents an experimental study on the efficiency of external strengthening of lightweight concrete damaged beams using CFRP sheets.

\section{EXPERIMENTAL PROGRAM}

The experimental work included six reinforced concrete beams, as summarized in Table 1: Two beams were normal concrete and the others were lightweight aggregate concrete (volumetric replacement of normal aggregate $50 \%$ and $75 \%$ by pumice respectively). To get the lightweight concrete, the natural aggregate (pumice) was used. Pumice is a natural lightweight aggregate of claystone. It's available as a cellular concrete block. The maximum aggregate size of the pumice was $12.5 \mathrm{~mm}$. The lightweight aggregates (pumice) absorb more water than normal aggregates because of the cellular structure of the pumice. To prevent continuous absorption of water by pumice that can cause a fast slump loss, the pumice was submerged in the water for 24 hours to reach saturation. Then, the water has been dripped off and the aggregate left for 24 hours in the laboratory to attain the saturated dry surface condition.

Table 1 Details of specimens

\begin{tabular}{|c|l|c|}
\hline Sample & \multicolumn{1}{|c|}{ Description } & \multicolumn{1}{c|}{ Strengthening Types } \\
\hline B1F & B1: Normal concrete & Full rehabilitation (for entire beam length) \\
\hline B2F & $\begin{array}{l}\text { B2: Lightweight aggregate } \\
\text { concrete 50\% replacement }\end{array}$ & Full rehabilitation (for entire beam length) \\
\hline B3F & $\begin{array}{l}\text { B3: Lightweight aggregate } \\
\text { concrete 75\% replacement }\end{array}$ & Full rehabilitation (for entire beam length) \\
\hline B4P & B4: Normal concrete & Partial rehabilitation (the middle-third of the beam) \\
\hline B5P & $\begin{array}{l}\text { B5: Lightweight aggregate } \\
\text { concrete 50\% replacement }\end{array}$ & Partial rehabilitation (the middle-third of the beam) \\
\hline B6P & $\begin{array}{l}\text { B6: Lightweight aggregate } \\
\text { concrete 75\% replacement }\end{array}$ & Partial rehabilitation (the middle-third of the beam) \\
\hline
\end{tabular}


The beam specimen was $1600 \mathrm{~mm}$ long with a clear span of $1500 \mathrm{~mm}$ and with the detailed dimensions of $\left(b_{w}=80 \mathrm{~mm}, h=240 \mathrm{~mm}, b_{f}=180 \mathrm{~mm}, t_{f}=40 \mathrm{~mm}\right)$. The I-shape beams were reinforced with $2 \emptyset 12 \mathrm{~mm}$ longitudinal reinforcing bars at the bottom, with $2 \emptyset 10 \mathrm{~mm}$ longitudinal bars at the top, and $\emptyset 6 \mathrm{~mm}$ stirrups at $75 \mathrm{~mm}$ center to center. The steel reinforcement was fabricated according to ASTM A615 (2018). The reinforcement details are shown in Figure 1 and the properties of steel are given in Table 2.

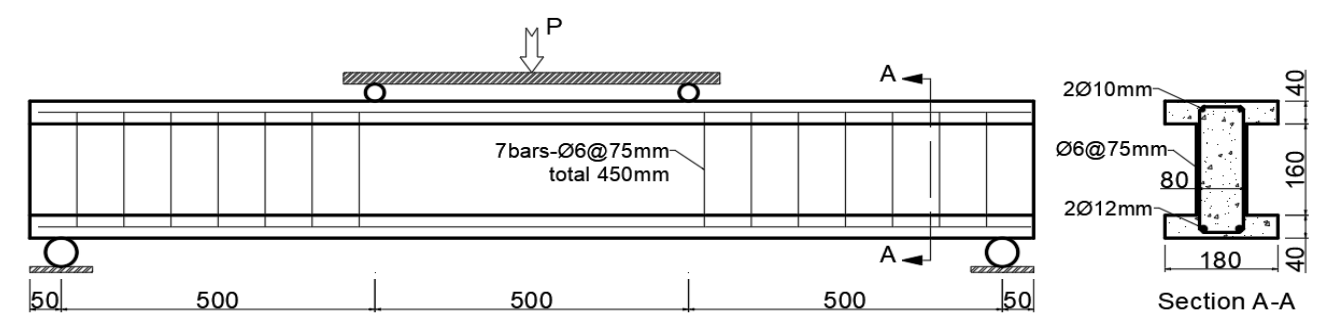

The beams have been tested under a two-point load test, as shown in Figure 1. In the first test, the beams were loaded until the theoretical yielding stress of reinforcing bars. In the second test, the beams were strengthened and loaded until failure.

Figure 1 Beam Dimensions and steel details

Table 2 Properties of steel rebar

\begin{tabular}{|c|c|c|c|}
\hline $\begin{array}{c}\text { Diameter } \\
(\mathbf{m m})\end{array}$ & $\begin{array}{c}\text { Yield strength } \\
(\mathbf{M P a})\end{array}$ & $\begin{array}{c}\text { Ultimate strength } \\
\text { (MPa) }\end{array}$ & Steel grade \\
\hline 6 & 370 & 540 & Grade 40 \\
\hline 10 & 573 & 675 & Grade 60 \\
\hline 12 & 420 & 627 & Grade 60 \\
\hline
\end{tabular}

All the beams are repaired with CFRP sheets in the tension face. The unidirectional carbon fiber reinforced polymer type (DCP-Profiber CW230) was used for rehabilitation of the reinforced concrete beam. The CFRP sheet thickness is $0.0131 \mathrm{~mm}$ and it has a modulus of elasticity of $230 \mathrm{GPa}$ and a tensile strength of $4.9 \mathrm{GPa}$ with extreme elongation of $2.1 \%$. 
Figure $2(a \& b)$ shows the strengthening scheme for the reinforced concrete elements, where three beams have full-length sheets along its span, while the remaining specimens rehabilitated using CFRP laminates bonded to the middle-third length bottom face of the beam (partial strengthening). It's worthy to note here that all the beams strengthened with CFRP were completely coated with epoxy. The CFRP sheets have been bonded to the bottom face of specimens as follows: the bottom face was cleaned using an iron brush and blown with air, a primer was applied on the surface and left for 24- hours. After that, the first layer of resin (Quickmast ER350) with the DCP-Profiber CW230 sheet has been applied. Finally, the second layer of resin was applied and left for two days before the test.

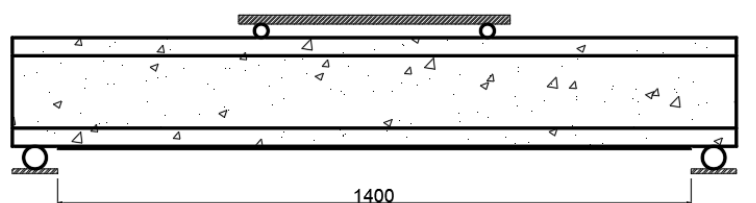

(a) full strengthening of the beam

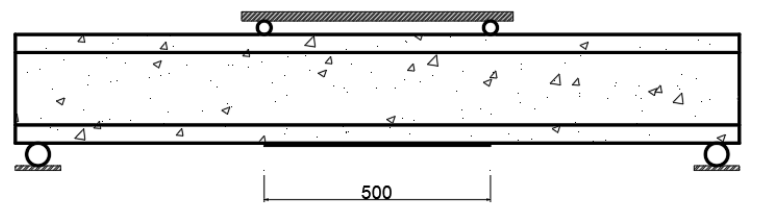

(b) partial strengthening of the beam

Figure 2 Strengthening sketch

As mentioned before, the specimens were tested under a two-point loading test. The load was applied by using a hydraulic testing machine of capacity equal to $300 \mathrm{kN}$. The deflection of the beam was measured at the mid-span by using a dial gauge of $0.01 \mathrm{~mm}$ accuracy. The load was increased slowly where the data was recorded every $2.5 \mathrm{kN}$ load increments until failure occurred.

Many trials-mixed had been tried before starting the cast of the main beams. Finally, the mixed was proportioned to have concrete strength (f'c) for 28 days-age equal to $36.2 \mathrm{MPa}$. After replacing $50 \%$ and $75 \%$ of the coarse aggregate with Light pumice, the strength of concrete was dropped to 21.1 MPa and 18 MPa respectively. 
The grading of fine and coarse aggregates were lied within the ranges defined by IQS No.45 (1984) while some deviation was recorded when comparing the results with ASTM specification. The results are shown in Tables 3 and 4 respectively, while the physical properties of pumice are given in Table 5.

Table 3 Grading of fine aggregate

\begin{tabular}{|c|c|c|c|}
\hline $\begin{array}{c}\text { Sieve size } \\
(\mathrm{mm})\end{array}$ & $\begin{array}{c}\text { Limit of } \\
\text { ASTM C33- } \\
09\end{array}$ & $\begin{array}{c}\text { Limit of Iraqi } \\
\text { specification } \\
\text { No. 45, 1984 }\end{array}$ & $\begin{array}{c}\text { Cumulative } \\
\text { passing \% }\end{array}$ \\
\hline $9.5 \mathrm{~mm}$ & 100 & 100 & 100 \\
\hline 4.75 & $95-100$ & $90-100$ & 90.1 \\
\hline 2.36 & $80-100$ & $60-95$ & 63.4 \\
\hline 1.18 & $50-85$ & $30-70$ & 48 \\
\hline 0.6 & $25-60$ & $15-34$ & 29.7 \\
\hline 0.3 & $5-30$ & $5-20$ & 7.7 \\
\hline 0.15 & $0-10$ & $0-10$ & 1.1 \\
\hline
\end{tabular}

Table 4 Grading of coarse aggregate

\begin{tabular}{|c|c|c|}
\hline $\begin{array}{c}\text { Sieve size } \\
\text { (mm) }\end{array}$ & $\begin{array}{c}\text { Limit of ASTM } \\
\text { C33-09 }\end{array}$ & $\begin{array}{c}\text { Cumulative } \\
\text { passing } \%\end{array}$ \\
\hline $19.0 \mathrm{~mm}$ & 100 & 100 \\
\hline $12.5 \mathrm{~mm}$ & $90-100$ & 97.4 \\
\hline $9.5 \mathrm{~mm}$ & 40 to 70 & 75 \\
\hline $4.75 \mathrm{~mm}$ & 0 to 15 & 6.1 \\
\hline $2.36 \mathrm{~mm}$ & 0 to 5 & 1.7 \\
\hline
\end{tabular}

Table 5 Properties of pumice aggregate

\begin{tabular}{|c|c|c|c|}
\hline Properties & Specification & $\begin{array}{c}\text { Test } \\
\text { results }\end{array}$ & $\begin{array}{c}\text { Limit of } \\
\text { specification }\end{array}$ \\
\hline Sulfate content \% & $\begin{array}{c}\text { Iraqi specification } \\
\text { No.45, 1984 }\end{array}$ & 0.2 & 1 (max. value) \\
\hline Specific gravity & ASTM C127, 2015 & 1.6 & --- \\
\hline Absorption \% & ASTM C127, 2015 & 29 & --- \\
\hline $\begin{array}{c}\text { Dry loose unit } \\
\text { weight, } \mathrm{Kg} / \mathrm{m}^{3}\end{array}$ & $\begin{array}{c}\text { ASTM:C29/C29M, } \\
2009\end{array}$ & 576 & --- \\
\hline
\end{tabular}

Table 6 Physical properties of cement

\begin{tabular}{|l|c|c|c|}
\hline \multicolumn{1}{|c|}{$\begin{array}{c}\text { Physical } \\
\text { properties }\end{array}$} & ASTM specification & $\begin{array}{c}\text { Limits of Iraqi } \\
\text { Specification No.5 } \\
\mathbf{( 1 9 8 4 )}\end{array}$ & $\begin{array}{c}\text { Test } \\
\text { results }\end{array}$ \\
\hline $\begin{array}{l}\text { Compressive } \\
\text { strength (MPa) } \\
\text { for: 3-days } \\
7 \text {-days }\end{array}$ & ASTM C150-17 & & \\
\hline $\begin{array}{l}\text { Specific surface } \\
\text { area }\left(\mathrm{m}^{2} / \mathrm{kg}\right)\end{array}$ & Not less than $12 \mathrm{MPa}$ & $\begin{array}{c}\text { Not less than } 15 \mathrm{MPa} \\
\text { Not less than } 23 \mathrm{MPa}\end{array}$ & 17.2 \\
28
\end{tabular}




\begin{tabular}{|l|c|c|c|}
\hline $\begin{array}{l}\text { Setting time } \\
\text { (vacate Test) }\end{array}$ & ASTM C191-99 & \\
$\begin{array}{l}\text { Initial setting } \\
\text { (hrs.: min) }\end{array}$ & Not less than 45min & Not less than 45min & $3 \mathrm{hr}$ \\
$\begin{array}{l}\text { Final setting } \\
\text { (hrs.: } \mathrm{min})\end{array}$ & Not more than 6hrs:25 min & Not more than 10hrs & 4hrs:05min \\
\hline
\end{tabular}

Table 6 shows the physical properties of the cement that used in this research according to Iraqi and ASTM specifications.

\section{RESULTS AND DISCUSSIONS}

To investigate the behavior and rigidity of the lightweight concrete structures strengthened by CFRP sheets, the load-deflection curve is analyzed. All the beams were loaded up to the theoretical failure loads. These loads were calculated according to the simple bending theory of reinforced concrete beams (ACI 318M-19) as shown in Table 7. The effective depth of rebar was $220 \mathrm{~mm}$, and the beam width was $180 \mathrm{~mm}$. The strength reduction factor $(\phi)$ was ignored in these calculations to quantify the actual strength of specimens.

Table 7 Primary strength of reinforced concrete beams

\begin{tabular}{|l|c|c|c|c|}
\hline \multicolumn{1}{|c|}{ Concrete Type } & $\begin{array}{c}\text { Concrete } \\
\text { Strength } \\
\text { (MPa) }\end{array}$ & $\begin{array}{c}\text { a ( depth of } \\
\text { Whitney stress } \\
\text { block) mm }\end{array}$ & $\begin{array}{c}\text { Moment Capacity } \\
\text { of Beams (kN .m) }\end{array}$ & $\mathrm{P}_{\mathrm{u}}(\mathrm{kN})$ \\
\hline Normal concrete & 36.2 & 17.14 & 20.07 & 80.28 \\
\hline $\begin{array}{l}\text { Lightweight } \\
\text { aggregate concrete } \\
50 \% \text { replacement }\end{array}$ & 21.1 & 29.40 & 19.45 & 77.80 \\
\hline $\begin{array}{l}\text { Lightweight } \\
\text { aggregate concrete } \\
75 \% \text { replacement }\end{array}$ & 18 & 34.46 & 19.25 & 77.04 \\
\hline
\end{tabular}

In the first stage, the beams were loaded until the primary strength of the beams, where sever cracks were developed. These cracks started from the bottom face of the beam near the mid-span region (tension cracks). Moreover, diagonal cracks appear near the support and extended until they reach the top of the flange of the beams (compression zone). In this stage, the loading process was stopped. The load-deflection curved was drawn for all the samples. The recorded loads in this phase were considered as failure load since it is the most reachable value without 
causing permanent unfixable damage for the beams. All the beams are designed as under reinforcing condition, therefore the concrete compression failure was avoided in this stage. After removing the applied loads, the specimens restored its original shape with some permanent deformation (deflection) due to concrete cracks and reduction of the rigidity of the samples, as shown in Figure 4. The previously opened cracks were closed partially after removing of loads according to their places and orientation.

Figure 3 cracks in the reference beam, B1

In the second stage, all the beams were rehabilitated using carbon fiber sheets. Three beams were rehabilitated along their entire length $(\mathrm{B} 1 \mathrm{~F}, \mathrm{~B} 2 \mathrm{~F}$, and $\mathrm{B} 3 \mathrm{~F})$, while the rest were strengthened through their middle-third span (B4P, B5P, and B6P). The results show that CFRP sheets assist to achieve a large percentage of the member's ductility concerning the deflection features, (Figure 4).

Concerning failure mode, the entire length strengthened beam with CFRP showed flexural cracks and debonding failure mode at a later stage of loading. Those cracks prolonged from the main cracks occurred in the original tested beam and continued until the failure. At the final loading steps, the CFRP sheets began to separate from the beams at its endpoints. For the partial strengthening beams (B4P, B5P, and B6P), the cracks developed at the region behind the sheets, where the moment and corresponding stresses are still at a high level, leading to typical flexural failure, as shown in Figure 5. 


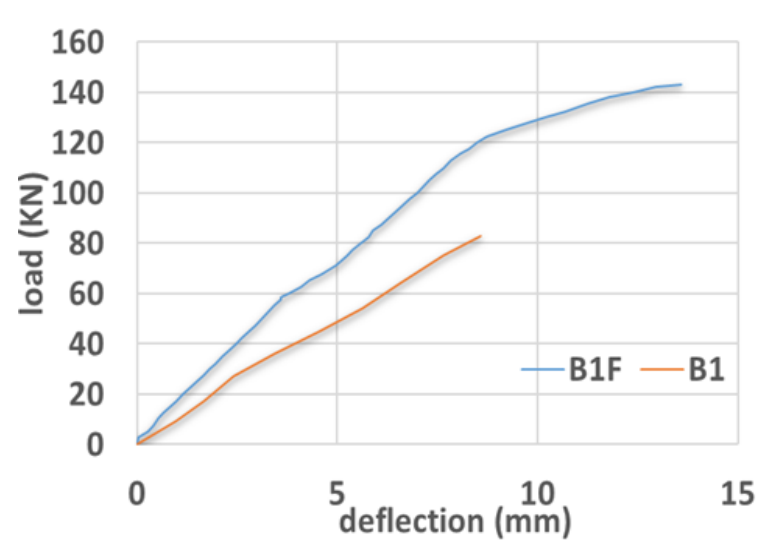

a): Reference beam, B1

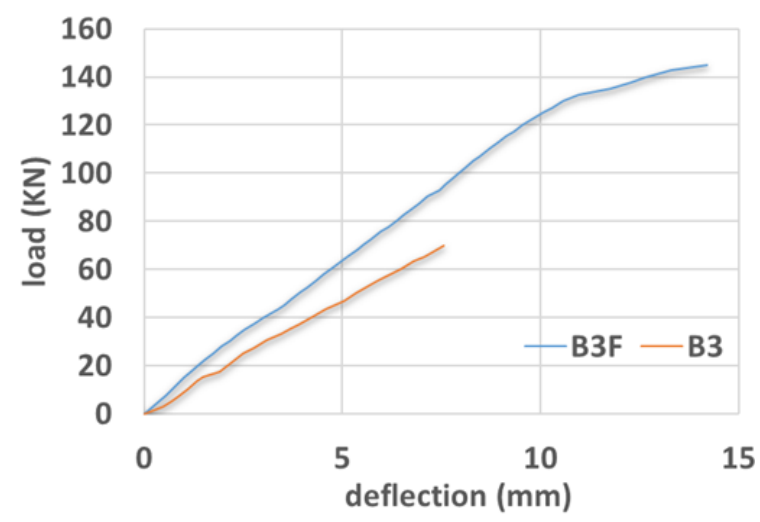

c): LWC $75 \%$ replacement, B3

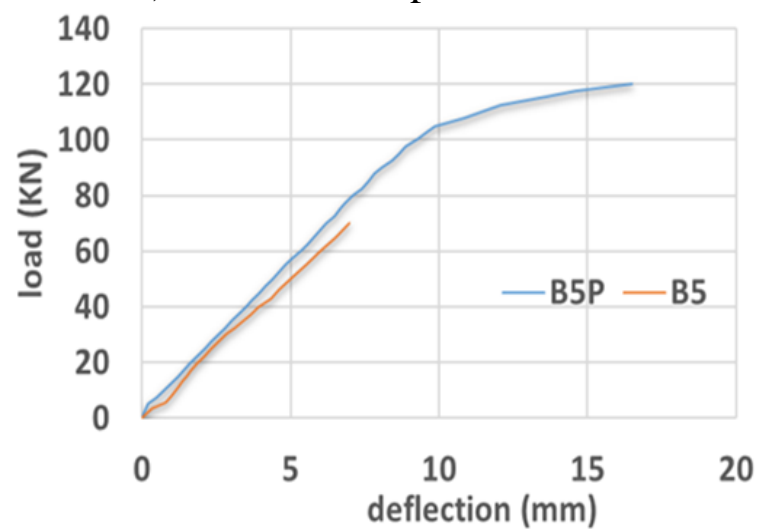

e): LWC 50\% replacement, B5

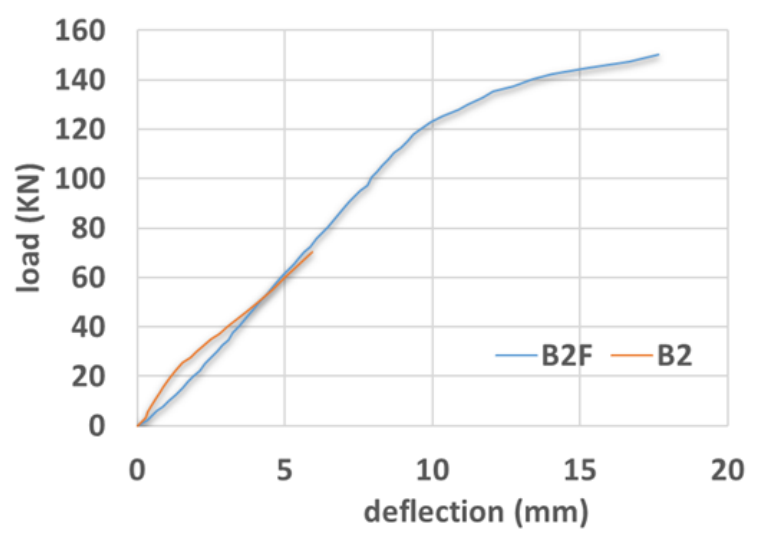

b): LWC $50 \%$ replacement, B2

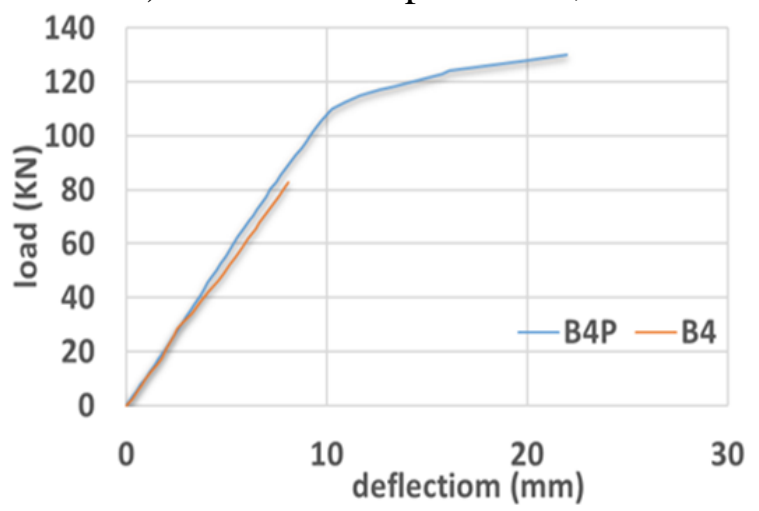

d): Reference beam, B4

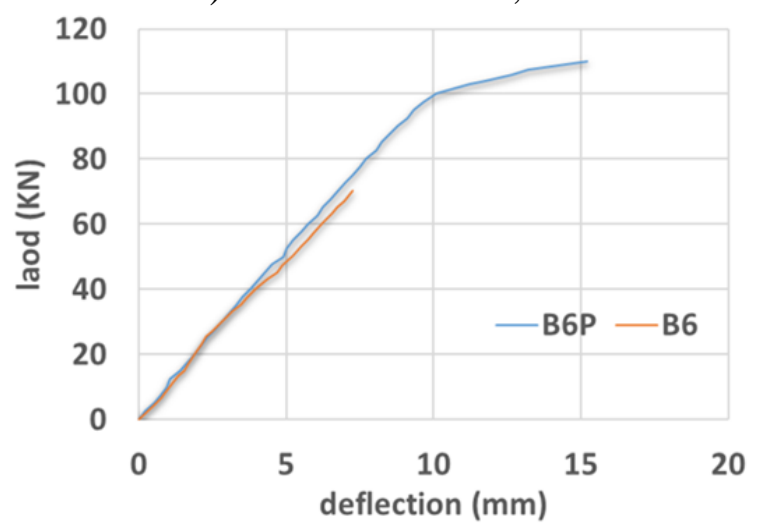

f): LWC $75 \%$ replacement, B6

Figure 4 Load-deflection curve for beams.

Table 8 summarizes the failure load and mid-span deflection. $\mathrm{P}_{\mathrm{u}}$ and $\mathrm{P}_{\mathrm{cr}}$ are the ultimate strength of the primary and strengthened beams, respectively, while $\delta_{\mathrm{u}}$ and $\delta_{\mathrm{cr}}$ are the mid-span deflection of the primary and strengthened beams. Figure 4 shows the load-deflection curve for all the specimens in the research.

For the beams strengthened with CFRP along the entire length of the beams (B1F, B2F, and $\mathrm{B} 3 \mathrm{~F})$, the maximum load increased by $(75 \%, 113 \%$ and $107 \%)$. This indicates that 
significant improvement in load-carrying capacity can be achieved by using CFRP sheets. Investigation of Table 8 shows that beams B1F and B4P have approximately the same initial load carrying-capacity 83 and 82.8 (Table 8) as they have the same initial design criteria (concrete strength and reinforcement). After the application of sheets, the strength enhancement was $75 \%$ and $64 \%$ respectively, indicating that the use of full-length strengthening better than the middle-third. The short strips of CFRP lead to concentrated tension-stresses at the region directly after strip, and thus the development of diagonal prolong cracking directly upward to the top flange of beams, therefore, resulting in earlier failure of the elements (Figure 5, b).

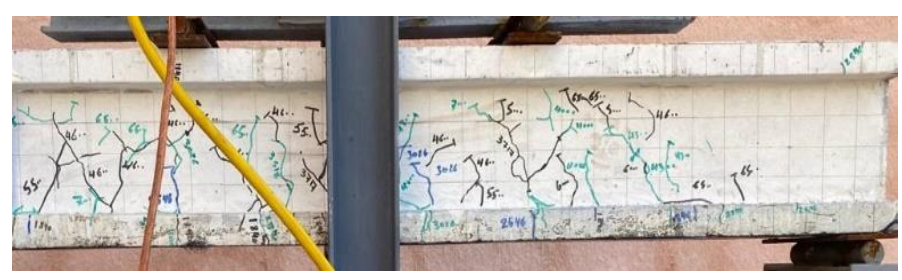

(a) Full-length strengthening

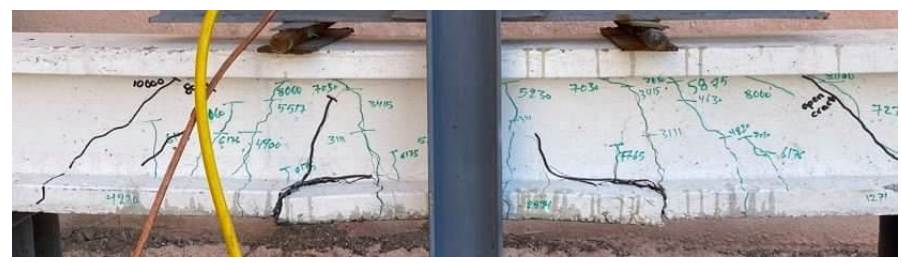

(b) Partial strengthening of the beam

Figure 5 Crack pattern of beam partial strengthened with CFRP.

It is worth to mention, the initial strengths of B2F, B3F, B5P, and B6P were the same, although they have different aggregate replacements (Table 1). This indicates that pumice reduces the strength of the beams by the same percentage when it is applied with large amounts in the concrete mix (84\% of reference beam, Figure 7 ).

Another important notice can be referred here, the ultimate strength of the beams (B4P, B5P, and B6P) decreases with using lightweight aggregate comparing with (B1F, B2F and, B3F) and that is a proof that the full-length strengthening method improves the beams more effectively than the partial strengthening method especially in lightweight structures. 
Figure 6 presents the load-defection curve for all the beams, and it is obvious that the concrete beams have ductile behaviors with deferent percents. However, all the specimens undergo a plastic zone at the same value $(10 \mathrm{~mm})$. This is the point where the steel reinforcement starts to yield and the curvature of the beams increases in a rapidly.

Table 8 Experimental test results of beams

\begin{tabular}{|c|c|c|c|c|c|c|}
\hline \multirow{2}{*}{ Specimens } & \multicolumn{2}{|c|}{ Load $(\mathbf{K N})$} & \multicolumn{2}{|c|}{ Deflection $(\mathbf{m m})$} & \multirow{2}{\text{Increasein}}{ Mode of failure } \\
\cline { 2 - 5 } & $\mathbf{P}_{\mathbf{u}}$ & $\mathbf{P}_{\mathbf{c r}}$ & $\boldsymbol{\delta}_{\mathbf{u}}$ & $\boldsymbol{\delta}_{\mathbf{c r}}$ & strength \% & \\
\hline B1F & 83 & 145.4 & 8.6 & 13.6 & 75 & Flexural+ debond \\
\hline B2F & 70.4 & 150 & 5.9 & 17.7 & 113 & Flexural+ debond \\
\hline B3F & 70.1 & 145 & 7.6 & 14.2 & 107 & Flexural+ debond \\
\hline B4P & 82.8 & 136 & 8.1 & 22 & 64 & Flexural \\
\hline B5P & 70 & 120 & 7 & 16.5 & 72 & Flexural \\
\hline B6P & 70.2 & 110 & 7.2 & 15.2 & 57 & Flexural \\
\hline
\end{tabular}

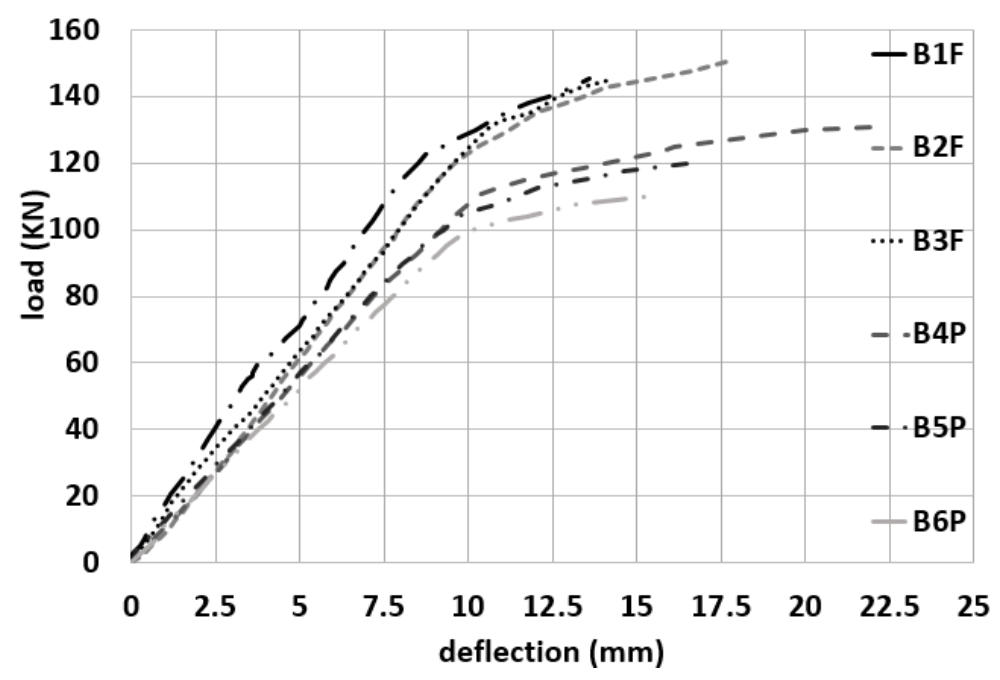

Figure 6 Load-deflection curve for all beams strengthened with CFRP 


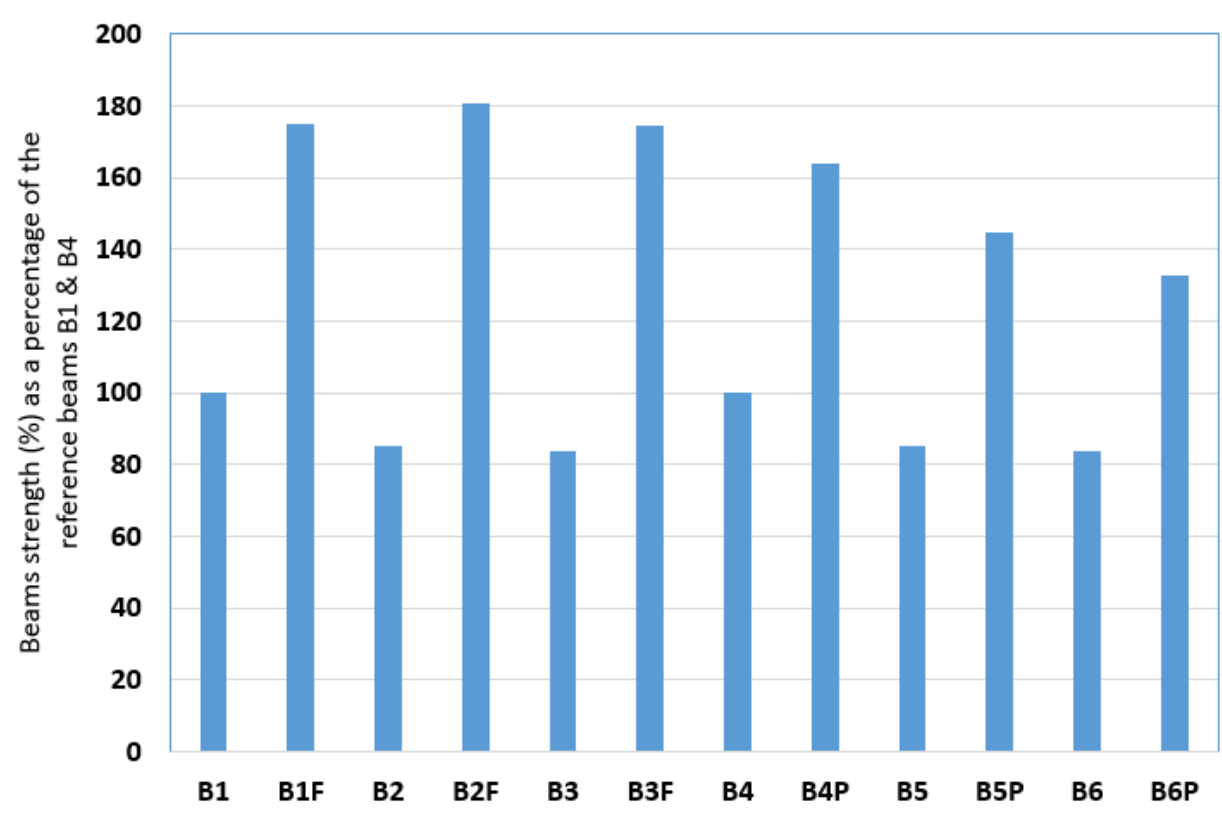

Figure 7 Beams strength as a percent of the reference beams B1 \& B4

Figure 7 presents the beams strength ratio as a percent of the reference beams (B1\&B4), where any results above $100 \%$ represent increasing strength while the results below represent the decrease in strength compared with reference beams. For un retrofitted members (B1 B6), it is evident that lightweight members have lower strength than Tnormal-weight concrete members. The member with $50 \%$ replacement of aggregate with pumice and had full-length strengthening (B2F) gave the most efficient results based on comparison with the reference beam (B1) or itself member before retrofitting (B2).

\section{CONCLUSIONS}

This study presented the results of an experimental work that investigates the flexural behavior of the lightweight concrete strengthened with CFRP. The followings may be concluded:

- Strengthening of CFRP significantly improved the efficiency of reinforced lightweight concrete beams $(57 \%-113 \%)$.

- Although the debonding of CFRP sheets occurs at a late stage of loading, full ductile behaviors have been achieved for the specimens. 
- The load-carrying capacity was increased by $75 \%, 113 \%$, and $107 \%$ for whole length strengthened beams compared with the same beams before strengthening.

- The load-carrying capacity was increased by $64 \%, 72 \%$, and $57 \%$ for middle-third length strengthened beams, compared with the same beams before strengthening.

- Using the full-length sheets improves the behavior of the concrete beams much better than the middle-third strengthening.

- Increasing the percent of pumice in the aggregate (from $50 \%$ to $75 \%$ ) decreases the ultimate strength of the retrofit structure by $3.33 \%$ for full-length strengthening (B2F\& B3F), while for partial strengthened beams (B5P\&B6P), the decrease ratio at the same stage was $8.33 \%$.

- The failure mode for beams with full-length strengthening was sheet debonding while typical flexural failure mode was observed for partial strengthening.

- The strengths of lightweight concrete beams with (50\% replacement of aggregate with pumice, and $75 \%$ replacement of aggregate with pumice) were $85 \%$ and $84 \%$ respectively with compare to normal weight aggregate concrete.

\section{ACKNOWLEDGMENT}

This study was carried out in the Civil Engineering laboratory- College of Engineering, University of Kirkuk. The support of the Civil Engineering Department therefore gratefully acknowledged. Our special thanks and gratitude to Dr. Aram M. Raheem for his support, help, and encouragement during this research.

\section{REFERENCES}

ACI 318M, 2019. Building Code Requirements for Structural Concrete. ACI Committee 318. American Concrete Institute, Michigan. 
ACI 440.2R, 2017. Guide for the Design and Construction of Externally Bonded FRP Systems for Strengthening Concrete Structure. ACI Committee 440, American Concrete Institute, Michigan.

Al-Mamoori, F. H. 2018. Production of structural lightweight aggregate concrete using different types of Iraqi local crushed materials as coarse aggregate. Journal of University of Babylon, Engineering Sciences, 26(1), 362-375.

Al- Rawi, Q.S. 1995. Properties of lightweight concrete made of local porcelain aggregate. Master's thesis, University of Baghdad.

ASTM C29/C29M, 2009. Standard Test Method for Bulk Density (Unit Weight) and Voids in Aggregate. American Society for Testing and Materials, Pennsylvania, USA.

ASTM C33, 2009. Standard Test Method for Concrete Aggregate. American Society for Testing and Materials, Pennsylvania, USA.

ASTM C127, 2015. Standard Test Method for Relative Density (Specific Gravity) and Absorption of Coarse Aggregate. American Society for Testing and Materials, Pennsylvania, USA.

ASTM C150, 2017. Standard Specification for Portland Cement. American Society for Testing and Materials, Pennsylvania, USA.

ASTM C191, 1999. Standard Test Method for Time of Setting of Hydraulic Cement by Vicat Needle. American Society for Testing and Materials, Pennsylvania, USA.

ASTM C330, 2017. Standard Specification for Lightweight Aggregates for Structural Concrete. American Society for Testing and Materials, Pennsylvania, USA.

ASTM A615, 2018. Standard specification for deformed and plain carbon-steel bars for concrete reinforcement. American Society for Testing and Materials, Pennsylvania, USA. 
Benjeddou, O., Ouezdou, M., \&Bedday, A. 2007. Damaged RC beams repaired by bonding of CFRP laminates. Construction and Building Materials, 21, 1301-1310.

Bonacci, J. F., \&Maalej, M. 2001. Behavioral trends of RC beams strengthened with externally bonded FRP plates. Journal of Composites for Construction, 5(2), 102-113.

Danraka, M. N., Mahmod, H. M. \&Oluwatosin, J. 2017. Strengthening of Reinforced Concrete Beams using FRP Technique: A Review. International Journal of Engineering Science and Computing, 7(8), 13199-13213.

Dushimimana, A., Ziada, M., \&Tuhta, S. 2018. Effect of carbon fiber reinforced polymer (CFRP) composites applied to walls and slabs of masonry building. International Journal of Advance Engineering and Research Development, 5(04), 2434-2442.

Faza, SS, \& Ganga, R. 1994. Fiber composite wrap for rehabilitation of concrete structures.Proceedings of the materials engineering conference 804, ASCE, 1135-9.

Ghaidan, D. J. 2018. Structural behavior of layered section reinforced lightweight concrete Ishaped beam with openings in web. Master's thesis, University of Tikrit.

Hussein, S. H., Hasan, Q. O., \&Alzaidi, M. 2016. Statistical modeling for verification of deflection for lightweight reinforced concrete beams with openings. International Journal of Science, Engineering and Technology Research IJSETR, 5(12), 3398-3405.

Iraqi Specification Standards, IQS No.45, 1984. Aggregate from Natural Sources for Concrete and Construction. Central Agency for Standardization and Quality Control, Planning Council, Baghdad, Iraq.

Khandaker, M., \& Hossain, A. 2004. Properties of volcanic pumice based cement and lightweight concrete. Cement and Concrete Research, 34, 283-291.

Nanni, A. 1999. Composites: coming on strong. Concrete Construction, 44, 120-4. 
Omer, W., \& Mohamed, R. N. 2002. The Performance of pre-tensioned pre-stressed concrete beams made with lightweight concrete. Malaysian Journal of Civil Engineering, 14(1).

Ramanaa, V., Kant, T., Morton, S.E.,Dutta, P.K., Mukherjee, A. \&Desai, Y.M., 2000. Behavior of CFRPC strengthened reinforced concrete beams with varying degrees of strengthening. Composites Part B: Engineering, 31(6-7), 461-470.

Shbeeb, N. I., Al-Akhras, N. M., Shannag, M. J., \& Alfendi, H. R. 2012. Strengthening of lightweight reinforced concrete slabs using different techniques. The IES Journal Part A: Civil \& Structural Engineering, 5(1), 16-27.

Soudik, K., El-Salakawy, E., \& Craig, B. 2007. Behavior of CFRP strengthened reinforced concrete beams in corrosive environment. Journal of Composites and Construction, 11(3), 291298.

Xu, Y., Jaing, L., XU, J.,\& Li, Y. 2012. Mechanical properties of expanded polystyrene lightweight aggregate concrete and brick. Construction and Building Materials, 27(1), 32-38.

Yazdani, N., \& Goucher, E. 2015. Increasing durability of lightweight concrete through FRP wrap. Composite Part B: Engineering, 82, 166-172.

Zaman, A., Gutub, S. A., \& Wafa, M. A. 2013. A review on FRP composites applications and durability concerns in the construction sector. Journal of Reinforced Plastics and Composites, 32(24), 1966-1988.

Ziraba, Y. N., Baluch, M. H., Basunbul, I. A., Sharif, A. M., Azad, A. K., \& Al-Sulaimani, G. J. 1994. Guidelines toward the design of reinforced concrete beams with external plates. ACI Structural Journal, 91(6), 639-646. 